\title{
Effect of Curing Temperature on Corrosion Resistance of a Chromium-free Coating on Hot Dip Galvanized Steel Sheet
}

\author{
Shan Liu ${ }^{1}$, Zhefeng $X u^{2,3}$, Jianhong $Y i^{3, *}$ \\ ${ }^{1}$ Department of Biological and Chemical Engineering, Panzhihua University, 617000, Panzhihua, P.R. \\ China. \\ ${ }^{2}$ PanGang Group Research Institute Co., Ltd., State Key Laboratory of Vanadium and Titanium \\ Resources Comprehensive Utilization, Panzhihua 617000, Sichuan, P.R. China. \\ ${ }^{3}$ Faculty of Materials Science and Engineering, Kunming University of Science and Technology, \\ Kunming 650093, P.R. China. \\ *E-mail: chuannong2010@126.com
}

doi: $10.20964 / 2018.07 .09$

Received: 26 February 2018 / Accepted: 16 April 2018 / Published: 5 June 2018

In this work, tannic acid powder, fluoro titanic acid solution and colloidal silica were used to prepare a coating on a hot dip galvanized steel sheet. The $\mathrm{pH}$ value of the passivating solution ranges between $2 \sim 7$, and the curing temperature is $20^{\circ} \mathrm{C}, 60{ }^{\circ} \mathrm{C}, 80^{\circ} \mathrm{C}$ and $100{ }^{\circ} \mathrm{C}$. The interface connectivity of the coating was investigated using a Fourier transform infrared spectrometer. Microstructures of the coating were observed using a field-emission scanning electron microscope equipped with an energy dispersive spectrometer and an X-ray photoelectron spectrometer. The corrosion resistance of the coating was studied using an electrochemical workstation. The results show that the coating thickness increased with increasing curing temperature. A coating thickness of $0.62 \mu \mathrm{m}$ is achieved with a curing temperature of $100{ }^{\circ} \mathrm{C}$; at this temperature, the corrosion potential Ecorr is $410.5 \mathrm{mV}$, and the polarization resistance $(\mathrm{Rp})$ is $2.13 \times 10^{6} \mathrm{~cm}^{-2} \mathrm{ohms}$. These conditions provided the best corrosion resistance of the coating.

Keywords: Curing temperature; hot dip galvanized steel sheet; coating; corrosion resistance; microstructure

\section{FULL TEXT}

(C) 2018 The Authors. Published by ESG (www.electrochemsci.org). This article is an open access article distributed under the terms and conditions of the Creative Commons Attribution license (http://creativecommons.org/licenses/by/4.0/). 